\title{
HBeAg Status among Chronic Hepatitis B Patients at a Referral Hospital of Bangladesh
}

\author{
Majid $\mathrm{F}^{1}$, Moben $\mathrm{AL}^{2}$, Hussain $\mathrm{D}^{3}$, Khondaker $\mathrm{MFA}^{4}$
}

\begin{abstract}
Background: $\mathrm{HBeAg}$ status in chronic hepatitis B patients is important for outcome and treatment Objective: The purpose of the present study was to see the status of HBeAg Chronic Hepatitis B (CHB) patients. Methodology: This cross sectional study was conducted in the Department of Virology at Bangabandhu Sheikh Mujib Medical University (BSMMU), Dhaka between July 2010 to June 2011. Serologically diagnosed CHB patients were enrolled for the study. The HBV DNA was quantified. Samples were tested for $\mathrm{HBeAg}$ with ELISA kit. Results: A total of 200 serologically diagnosed CHB patients were enrolled for the study. Among the total study population, $\mathrm{HBeAg}$ positive $\mathrm{CHB}$ patients were $74(37 \%)$ cases and $\mathrm{HBeAg}$ negative patients were $126(63 \%)$ cases. Among the HBeAg negative patients, viral load was less and patients were significantly older. The mean viral load of HBeAg positive and $\mathrm{HBeAg}$ negative was $6.40 \pm 2.042$ and $2.83 \pm 2.55$ respectively. HBV DNA was a more reliable indicator of the presence of virus than $\mathrm{HBeAg}$, and was detected in $98.65 \%(73 / 74) \mathrm{HBeAg}$ positive carriers, and in $66.67 \%(84 / 126) \mathrm{HBeAg}$ negative patients. Conclusion: $\mathrm{HBeAg}$ negativity is more prevalent among the $\mathrm{CHB}$ patients in Bangladesh. [J Shaheed Suhrawardy Med Coll, 2014;6(2):60-63]
\end{abstract}

Keywords: HBV DNA, CHB, HBeAg, Real time PCR

Received: March 2014; Revised: July 2014; Accepted: December 2014

\section{Introduction}

Hepatitis B virus (HBV) causes a spectrum of liver diseases including acute hepatitis, chronic hepatitis, liver cirrhosis, and hepatocellular carcinoma. Hepatitis $\mathrm{B}$ e antigen negative chronic hepatitis (e-CHB) with detectable levels of HBV DNA in serum has been reported in cases from Asia ${ }^{1}$. Globally, over 2 billion people are infected with Hepatitis B virus (HBV) and 370 million people are living with chronic $\mathrm{HBV}^{1}$. Among them, around 660,000 die annually due to consequences of this infection ${ }^{1}$. Bangladesh is a densely populated country with intermediate endemicity for chronic hepatitis B (CHB) infection ${ }^{2}$. Studies have shown that HBV is responsible for $31.25 \%$ cases of acute hepatitis, $76.3 \%$ cases of chronic hepatitis, $61.15 \%$ cases of cirrhosis of liver and $33.3 \%$ cases of hepatocellular carcinoma in Bangladesh ${ }^{3-5}$. The hepatitis B surface antigen (HBsAg) positivity among the healthy adult population of Bangladesh was $7.2 \%-7.5 \%{ }^{6-7}$. Serologic assays for HBV is the mainstay diagnostic tool for HBV infection. However, the advent of molecular biology based techniques has added a new dimension to the diagnosis and treatment of patients with chronic HBV infection ${ }^{8}$. Viral load tests that quantify HBV in peripheral blood like serum or plasma is currently the most useful and most widely used. High-sensitivity molecular assays are clearly important for the diagnosis of $\mathrm{HBeAg}$ negative $\mathrm{CHB}$ and occult $\mathrm{HBV}$, where viral loads can be quite low?

HBeAg-negative CHB is recognized as an important form of chronic hepatitis, where $\mathrm{HBeAg}$ negativity is due to mutations in pre-core and core promoter regions ${ }^{10}$. In HBeAg-negative Asian CHB patients, 45 to $57 \%$ have precore mutations and 41 to $70 \%$ have core promoter mutations ${ }^{11-12}$. Most studies believe that in Asian carriers, precore mutations are not responsible for disease progression $^{13}$, whereas, core promoter mutations may have some role in the development of cirrhosis-related complications ${ }^{13-14}$. Around $50 \%$ and $70 \%$ of patients clear HBeAg within 5 years and 10 years of diagnosis

1. Dr. Farjana Majid, Assistant Professor, Department of Microbiology, Tairunnessa Memorial Medical College, Gazipur

2. Dr. Ahmed Lutful Moben, Resident Physician, Department of Medicine, Shaheed Suhrawardy Medical College Hospital, Dhaka

3. Dr. Dilroze Hussain, Assistant Professor, Department of Physiology, Kumudini Women's Medical College, Tangail

4. Dr. Md. Faiz Ahmad Khondaker, Assistant Professor, Department of Hepatology, Shaheed Suhrawardy Medical College, Dhaka

Correspondence

Dr. Farjana Majid Assistant Professor, Department of Microbiology, Tairunnessa Memorial Medical College, Tongi, Gazipur; Cell No.: +8801714378251. Email: farjana_dr28@yahoo.com

Funding agency: None

Contribution to the authors: All authors designed the study acquired the data, conducted the data analysis, interpreted the data, and revised the manuscript, also participated in the language editing. All the authors approved the final document.

Conflict of Interest: Authors have declared no conflict of interest (financial or other) 
respectively ${ }^{15}$. In general, patients who clear $\mathrm{HBeAg}$ have a better prognosis than patients who remain $\mathrm{HBeAg}$ positive for prolonged periods of time ${ }^{16}$. It was thought that seroconversion from $\mathrm{HBeAg}$ to $\mathrm{HBeAb}$ is accompanied by cessation of HBV replication and remission of liver disease. The prevalence of $\mathrm{HBeAg}$ negative $\mathrm{CHB}$ were 39.7 to $51.3 \%$ from Bangladesh ${ }^{17-18}$, whereas, in Iran, Hong Kong and Korea the prevalence were $65 \%, 69 \%$ and $19.6 \%$, respectively ${ }^{19,11,20}$. In Europe, the prevalence of $\mathrm{HBeAg}$ negative variants in patients with CHB was $72 \%$ to $90 \%$ from France ${ }^{21}$, Italy ${ }^{22}$ and Greece ${ }^{23}$. Therefore the present study was undertaken to see the status of $\mathrm{HBeAg}$ chronic hepatitis B (CHB) patients.

\section{Methodology}

This cross sectional study was carried out among chronic HBV infected patient during the period of July 2010 to June 2011 for a period of 1(one) year. All the serologically diagnosed chronic hepatitis B patients at any age with both sexes who were referred to the Department of Virology at Bangabandhu Sheikh Mujib Medical University (BSMMU) were included as study population. Samples were selected by non probability convenience sampling method. Blood were collected using aseptic venipuncture technique. Approximately $5 \mathrm{~mL}$ venous blood were collected and placed into EDTA anticoagulant containing tube. The HBV DNA was quantified with a commercially available kit (RoboGene HBV DNA Quantification Kit, Lot no- 009, Germany) according to the manufacturer's instructions. Specimens were tested for $\mathrm{HBeAg}$ with a commercially available ELISA kit (Bio-Quant, Inc. UK) according to the manufacturer's instructions. Results were expressed as mean \pm standard deviation (SD) or percentage. Statistical analysis of HBV-DNA value was performed after $\log 10$ conversion. Fisher's Exact test and Mann-Whitney U test were used for comparison. Statistical analysis was made using SPSS 17.0 software, and $\mathrm{p}$-value of $<0.05$ considered as significant.

\section{Results}

In the present study $200 \mathrm{CHB}$ patients were included. The mean age with SD of the study population was $32.05 \pm 12.99$ years old with a range of 7 to 65 . The male was predominat than female with a ratio of $3.76: 1$. Among the total study population, $74(37 \%)$ cases were $\mathrm{HBeAg}$ positive and $126(63 \%)$ cases were $\mathrm{HBeAg}$ negative CHB patients. HBV DNA levels were $4.15 \pm 2.6$ by Real time PCR and ALT was $83.63 \pm 146.23 \mathrm{U} / \mathrm{ml}$ (Table 1).

Table 1: Baseline characteristics of study population $(n=200)$

\begin{tabular}{ll}
\hline Variables & Findings \\
\hline Age* & $32.05 \pm 12.99$ \\
Gender (male: female) & $3.76: 1$ \\
HBeAg & \\
$\quad *$ Positive & 74 \\
$\quad$ *Negative) & 126 \\
Serum ALT* & $83.63 \pm 146.23$ \\
HBV DNA load* & $4.15 \pm 2.93$ \\
\hline
\end{tabular}

${ }^{*}$ Mean \pm SD
The study populations were divided into 2 age groups of $<40$ and $>40$ years. Among all the CHB patients, $153(76.50 \%)$ were below 40 years of age. Of them, $63(41.18 \%)$ were $\mathrm{HBeAg}$ positive and the remaining $90(58.82 \%)$ were $\mathrm{HBeAg}$ negative. In contrast, $47(23.50 \%)$ patients were above 40 years. In this group, the majority $36(76.60 \%)$ were $\mathrm{HBeAg}$ negative, while $11(23.40 \%)$ were $\mathrm{HBeAg}$ positive. $\mathrm{HBeAg}$ positivity rate in younger patients were comparatively higher than older patients which was statistically significant $(\mathrm{p}<0.05)$ (Table 2$)$.

Table 2: Relation between age and HBeAg status $(n=200)$

\begin{tabular}{lcccc}
\hline Age group & \multicolumn{2}{c}{ HBeAg status } & Total & $\begin{array}{c}\mathbf{p} \\
\text { value }\end{array}$ \\
\cline { 2 - 3 } & Positive & Negative & & \\
\hline$<40 \mathrm{yrs}$ & $63(41.18)$ & $90(58.82)$ & $153(76.5)$ & \\
$>40 \mathrm{yrs}$ & $11(23.40)$ & $36(76.60)$ & $47(23.5)$ & $0.037^{*}$ \\
Total & $\mathbf{7 4 ( 3 7 )}$ & $\mathbf{1 1 6 ( 6 3 )}$ & $\mathbf{2 0 0 ( 1 0 0 )}$ & \\
\hline
\end{tabular}

*Fisher's Exact test was done; $\mathrm{P}<0.05$ indicates significant

In this study $\mathrm{HBeAg}$ positive $\mathrm{CHB}$ patients were $74(37 \%)$ cases and $\mathrm{HBeAg}$ negative patients were $126(63 \%)$ cases. Among all the $\mathrm{HBeAg}$ positive and negative patients, mean viral load was $6.40 \pm 2.04[\log 10($ copies $/ \mathrm{ml})]$ and $2.83 \pm 2.55[\log 10($ copies $/ \mathrm{ml})]$ respectively. Viral load of $\mathrm{HBeAg}$ positive patients was comparatively higher than $\mathrm{HBeAg}$ negative patients and this difference was highly significant $(\mathrm{p}=0.00)$. The mean ALT level was $134.35 \pm 193.03(\mathrm{U} / \mathrm{L})$ for $\mathrm{HBeAg}$ positive patients and $53.83 \pm 99.33$ (U/L) for $\mathrm{HBeAg}$ negative patients. Overall, HBV DNA and ALT level were significantly higher in $\mathrm{HBeAg}$ positive patients $(\mathrm{p}<0.05)$ (Table 3).

Table 3: HBV DNA by Real time PCR and ALT levels in relation to HBeAg status $(n=200)$

\begin{tabular}{llll}
\hline Variables & \multicolumn{2}{c}{ HBeAg status } & P value \\
\cline { 2 - 4 } & Positive & Negative & \\
\hline HBV DNA & $6.40 \pm 2.04$ & $2.83 \pm 2.55$ & 0.0001 \\
ALT (U/L) & $134.35 \pm 193.03$ & $53.83 \pm 99.33$ & 0.0001 \\
\hline
\end{tabular}

*Data are expressed as Mean $\pm \mathrm{SD}$; Mann-Whitney $\mathrm{U}$ test was done; $\mathrm{P}<0.05$ indicates significant; HBV DNA [log10 (copies/ml)]

\section{Discussions}

An estimated 350 million individuals in the world have chronic $\mathrm{HBV}$ infection. Although positive for HBsAg, most of them are $\mathrm{HBeAg}$ negative. $\mathrm{HBeAg}$ positivity is highly prevalent only in younger age groups of HBsAg carriers ${ }^{24-25}$. In current communitybased studies from different parts of the world, the prevalence of $\mathrm{HBeAg}$ negativity in chronic HBV infection has been found to range between $70 \%$ and $100 \%{ }^{26-30}$. The loss of HBeAg is usually associated with biochemical and histologic remission of hepatitis and with significant suppression in HBV replication ${ }^{24-31}$. Thus, the great majority of HBeAg-negative subjects have normal ALT levels and undetectable serum HBV DNA by the classic hybridization methods. However, with very sensitive techniques as the polymerase chain reaction (PCR) and the nested PCR assay, residual amounts of HBV DNA can be detected in the serum of most $\mathrm{HBeAg}$-negative subjects ${ }^{32}$.

The present study observed a significantly higher age among $\mathrm{HBeAg}$ negative patients. Another study shows that, the age of 
patients with $\mathrm{HBeAg-negative} \mathrm{CHB}$ ranges between 40 and 55 years $^{33}$. A study from the Department of Hepatology, BSMMU also was reported similar findings ${ }^{2}$. Previous studies were reported that only a few countries had more $\mathrm{HBeAg}$-negative than $\mathrm{HBeAg}$-positive CHB patients ${ }^{24}$. It is apparent that there is a worldwide increase in the prevalence of $\mathrm{HBeAg}$-negative $\mathrm{CHB}$. In Italy, $41 \%$ of patients with $\mathrm{CHB}$ were $\mathrm{HBeAg}$ negative during the period 1975 to 1985 , but in the last decade this increased to $90 \%{ }^{34}$. Due to mutation in core promoter and precore regions, $\mathrm{HBeAg}$ negativity occurs in CHB patients, which decrease or prevent the synthesis of $\mathrm{HBeAg}$ but do not impair viral replication ${ }^{35}$. In this present study, prevalence of HBeAg negative cases was $63 \%$. The HBeAg negative CHB was found $88.57 \%$ at the Department of Virology at BSMMU in 2010. Studies from the Department of Hepatology, BSMMU found $51.3 \% \mathrm{HBeAg}$ negative $\mathrm{CHB}^{36}$ and $39.7 \% \mathrm{HBeAg}$ negative $\mathrm{CHB}^{37}$. These results indicate a significant increase of $\mathrm{HBeAg}$ negative $\mathrm{CHB}$ among Bangladeshi population. This probably indicates that the majority of HBV positive patients in this region has been infected for a long time and has developed mutations in the pre-core region ${ }^{38}$.

The mean viral load of $\mathrm{HBeAg}$ positive and $\mathrm{HBeAg}$ negative patients in the present study was $6.40 \pm 2.04[\log 10$ (copies $/ \mathrm{ml}$ )] and $2.83 \pm 2.55[\log 10$ (copies $/ \mathrm{ml})]$ respectively. Previous studies show that in comparison to $\mathrm{HBeAg}$ positive $\mathrm{CHB}$ patients, $\mathrm{HBeAg}$ negative patients have lower serum HBV DNA and have more advanced disease as evidenced by liver histology ${ }^{39}$. Similar result was also observed in the present study. A study from Iran showed that HBV DNA levels were higher in HBeAg-positive patients, where $87 \%$ patients were negative for $\mathrm{HBeAg}^{40}$. In a study from Korea, it was observed that the median serum HBV DNA for $\mathrm{HBeAg}$ negative patients was approximately two log lower than $\mathrm{HBeAg}$ positive patient, regardless of ALT level ${ }^{41}$. A lower alanine aminotransferase level was reported among $\mathrm{HBeAg}$ negative patients from Italy ${ }^{42}$. A 6 years study conducted by the Department of Hepatology, BSMMU was showed that ALT and HBV DNA levels were significantly lower in HBeAg negative subjects ${ }^{2}$. Another study from Bangladesh showed high DNA load in $96 \% \mathrm{HBeAg}$ positive patients compared to only $54.1 \%$ among $\mathrm{HBeAg}$ negative patients ${ }^{43}$. In this study, HBV DNA and ALT level were also significantly lower in $\mathrm{HBeAg}$ negative patients. Another study was showed that the viral load in $\mathrm{HBeAg-positive}$ patients was higher than in $\mathrm{HBeAg}$-negative individual ${ }^{38}$. The mean ALT was significantly higher in HBeAg-positive than in $\mathrm{HBe} A g$-negative patients, which could be due to a higher degree of inflammation.

\section{Conclusion}

In conclusion $\mathrm{HBeAg}$ negativity is more prevalent among the CHB patients in Bangladesh. Careful evaluation for the histological activity of HBV, functional status of the liver and presence of cirrhosis or hepatocellular carcinoma in $\mathrm{HBeAg}$ negative patient may be helpful for their further treatment. Patients who are HBeAg negative have lower viral load and have significantly older. ALT level is raised in patients with detectable HBV DNA. However, this study is limited by lack of determining the frequency of precore/core promoter mutation among $\mathrm{HBeAg}$ negative $\mathrm{CHB}$ patients. This aspects need to be evaluated further in future studies with large number of CHB patients.

\section{References}

1. CDC. Recommendations for Identification and Public Health Management of Persons with Chronic Hepatitis B Virus Infection. National Notifiable Diseases, 2008 2. Alam S, Ahmad N, Mustafa G, Alam K, Khan M. Characteristics of treatment naive chronic hepatitis B in Bangladesh: Younger populations are more effected; $\mathrm{E}$ antigen negatives are more advanced. Saudi J Gastroenterol 2008;14:15-19

3. Mahtab MA, Rahman S, Karim MF, Khan M. Epidemiology of hepatitis B virus in Bangladeshi general population. Hepatobiliary Pancreat Dis Int 2008;7(6): 595-600

4. Afroz S, Mahtab MA, Rahman S, Khan M. Hepatitis B virus is the leading cause of cirrhosis of liver in Bangladesh. Hepatol Int 2007;1: 120

5. Khan M, Zaki KMJ, Ahmed KU. Clinical profile: Prognostic index in hepatocellular carcinoma. Bangladesh Med Res Coun Bull 1991: 49-62.

6. Islam MN, Islam KM, Islam N. Hepatitis-B virus infection in Dhaka, Bangladesh. Bangladesh Med Res Coun Bull 1984; 10:1-6

7. Khan M, Ahmad N. Seroepidemiology of HBV and HCV in Bangladesh. Int Hepatol Comm 1996;5: 27-29

8. EASL Clinical Practice Guidelines. Management of chronic hepatitis B. J Hepatol 2009;50 : 227-242

9. Alexandra V. Molecular Testing in the Diagnosis and Management of Chronic Hepatitis B. Clin Microbiol Rev 2007;20 (3): 426-439.

10. Brunetto MR, Stemler M, Schodel F. Identification of HBV variants which cannot produce precore derived $\mathrm{HbeAg}$ and may be responsible for severe hepatitis. Ital J Gastroenterol 1989;21: 151-4

11. Chan HL, Leung NW, Hussain M, Wong ML, Lok AS (2000). Hepatitis B e antigen-negative chronic hepatitis B in Hong Kong. Hepatology 2000;31: 763-768 12. Yuen MF, Sablon E, Yuan HJ. Relationship between the development of precore and core promoter mutations and hepatitis $\mathrm{B}$ e antigen seroconversion in patients with chronic hepatitis B virus. J Infec Dis 2002;186: 1335- 1338

13. Yuen MF, Tanaka Y, Mizokami M. Role of hepatitis B virus genotypes Ba and $\mathrm{C}$, core promoter and precore mutations on hepatocellular carcinoma: a case control study. Carcinogenesis 2004;25: 153-1598

14. Liu CJ, Chen BF, Chen PJ. Role of hepatitis B virus precore ? core promoter mutations and serum viral load on noncirrhotic hepatocellular carcinoma: a casecontrol study. J Infect Dis 2006;194: 594-599

15. Fattovich G. Natural history and prognosis of hepatitis B. Semin Liver Dis 2003;23:47-58

16. Merican I, Guan R, Amarapuka D, Alexander M, Chutaputti A, Chien R, et al. Chronic hepatitis B virus infection in Asian countries. J Gastroenterol Hepatol2000;15:12, 1356-1361

17. Ahmad N, Alam S, Mustafa G, Adnan AB, Baig RH, Khan M. e-antigennegative chronic hepatitis $B$ in Bangladesh. Hepatobiliary Pancreat Dis Int 2008; 7: 379-382

18. Mahtab MA, Rahman S, Karim F. Clinical and histopathological characterization of asymptomatic hepatitis B virus positive subjects in Bangladesh. Acta Hep Japonica 2008d;49 (1):98

19. Yosefirad M, Malekzadeh R, Khatibian M. Prospective controlled trial of interferon alpha-2b in Iranian patients with chronic hepatitis B. Gastroenterol. 1997;112A: 1420.

20. Yoo BC, Park JW, Kim HJ, Lee DH, Cha YJ, Park SM. Precore and core promoter mutations of hepatitis $B$ virus and hepatitis $B$ e antigen-negative chronic hepatitis B in Korea. J Hepatol 2003;38: 98-103.

21. Zarski JP, Marcellin P, Leroy V, Trepo C, Samuel D, Ganne-Carrie N. Characteristics of patients with chronic hepatitis B in France: predominant frequency of HBe antigen negative cases. J Hepatol 2006;45:355-360.

22. Lampertico P, Del Ninno E, Manzin A, Donato MF, Rumi MG, Lunghi G (1997). A randomized, controlled trial of a 24-month course of interferon alfa $2 b$ in patients with chronic hepatitis B who had hepatitis B virus DNA without hepatitis B e antigen in serum. Hepatology 1997; 26:1621- 1625

23. Papatheodoridis GV, Manesis E \& Hadziyannis SJ. The longterm outcome of interferon-alpha treated and untreated patients with $\mathrm{HBeAg}$-negative chronic hepatitis B. J Hepatol 2001;34:306-313

24. Hadziyannis SJ. Hepatitis B e antigen negative chronic hepatitis B: from clinical recognition to pathogenesis and treatment. Viral Hepat Rev 1995;1:7-36

25. Lok AS, Lai CL, Wu PC, Leung EK, Lam TS. Spontaneous hepatitis B e antigen to antibody seroconversion and reversion in Chinese patients with chronic 
hepatitis B virus infection. Gastroenterology 1987;92: 1839-1843

26. Knoll A, Rohrhofer A, Kochanowski B, Wurm EM, Jilg W. Prevalence of precore mutants in anti-HBe-positive hepatitis B virus carriers in Germany. J Med Virol 1999;59:14-18

27. Chan HL, Leung NW, Hussain M, Wong ML, Lok AS. Hepatitis B e antigennegative chronic hepatitis B in Hong Kong. Hepatology 2000; 31:763-768.

28. Chowdhury A, Santra A, Chaudhuri S, Ghosh A, Banerjee P, Mazumder DN. Prevalence of hepatitis B infection in the general population: a rural community based study. Trop Gastroenterol 1999;20:75-77

29. Madzime S, Adem M, Mahomed K, Woelk GB, Mudzamiri S, Williams MA Hepatitis B virus infection among pregnant women delivering at Harare Maternity Hospital, Harare, Zimbabwe, 1996 to 1997. Cent Afr J Med 1999;45:195-198

30. Minuk GY, Orr PS, Brown R, Macdonald S, Chaudhary RK, Temple P. Precore mutant infections in the Canadian Inuit. J Hepatol 2000;33: 781-784

31. Chu CM, Liaw YF. Natural history of chronic hepatitis B virus infection: an immunopathological study. J Gastroenterol Hepatol 1997;12:S218-S222

32. Oketani M, Oketani K, Xiaohong C, Arima T. Low level wild-type and precore mutant hepatitis $\mathrm{B}$ viruses and $\mathrm{HBeAg}$ negative reactivation of chronic hepatitis B. J Med Virol 1999;58:332-337.

33. Hadziyannis SJ, Vassilopoulos D. Hepatitis B e Antigen-Negative Chronic Hepatitis B. Hepatology 2001;34 (4): 617-623

34. Rizzetto M, Volpes R \& Smedile A. Response of pre-core mutant chronic hepatitis B infection to lamivudine. J Med Virol 2000;61:398-402

35. Tran TT. Hepatitis B in Asian/Pacific islands:Overview and call to action. Adv Stud Med 2007;7(15):469-475

36. Mahtab MA, Rahman S, Karim F. Clinical and histopathological characterization of asymptomatic hepatitis B virus positive subjects in
Bangladesh. Acta Hep Japonica 2008b; 49 (1):98

37. Ahmad N, Alam S, Mustafa G, Adnan AB, Baig RH, Khan M. e-antigennegative chronic hepatitis B in Bangladesh. Hepatobiliary Pancreat Dis Int 2008;7: 379-382.

38. Tonetto PA, Neiva SL, Fais V, Aline G, V Eduardo SL, Gonçales Jr et al. Hepatitis B virus: molecular genotypes and $\mathrm{HBeAg}$ serological status among HBV-infected patients in the southeast of Brazil. BMC Infect Dis 2009;9:149 39. Pungpapong S, Kim WR, Poterucha JJ. Natural History of Hepatitis B Virus Infection. An Update for Clinicians. Mayo Clin Proc 2007;82: 967-975

40. Ganji A, Esmaeilzadeh A, Ghafarzadegan K, Helalat H, Rafatpanah H, Ali M. Correlation between HBsAg quantitative assay results and HBV DNA levels in chronic HBV. Hepat Month 2011;11 (5):342-345

41. Heo j, Baik TH, Kim HH, Ha Kim HG, Kang HD. Serum Hepatitis B Virus (HBV) DNA Levels at Different Stages of Clinical Course in Patients with Chronic HBV Infection in an Endemic Area. J Korean Med 2003;18: 686-90 42. Sagnelli E, Stroffolini T, Mele A, Imparato M,Almasio PL. Chronic Hepatitis $B$ in Italy: New Features of an Old Disease-Approaching the Universal Prevalenceof Hepatitis B e Antigen-Negative Cases and the Eradication of Hepatitis D Infection. CID, 2008

43. Mahtab MA, Rahman S, Kamal M, Khan M. Occult Hepatitis B Virus Related Decompensated Cirrhosis of Liver in Young Males: First Report of Two Cases from Bangladesh. Hepatitis Monthly 2008c; 8(2): 147-150 